\title{
BUDAYA MEMBACA DAN LEARNING BY \\ DOING PADA MASA PANDEMI COVID-19 UNTUK MEWUJUDKAN SDM YANG UNGGUL
}

\author{
Muhammad Iqbal Jauhar Hanim, S.Pd., M.Or. ${ }^{30}$ \\ Universitas Negeri Yogyakarta
}

"Kecerdasan seseorang dapat ditingkatkan melalui budaya membaca, sedangkan ketrampilan dapat ditingkatkan melalui pendekatan learning by doing. Sehingga kondisi pandemi saat ini mempunyai banyak waktu luang untuk membaca guna mewujudkan SDM yang unggul"

$S_{\text {hidup bagi sebagian orang Indonesia. Terdapat adagium }}^{\text {aat ini membaca sudah menjadi kebutuhan dan gaya }}$ menyatakan hobi membaca membuka jendela dunia. Tiada hari tanpa membaca diterapkan oleh orang yang hobi membaca. Dengan membaca, seseorang dapat memiliki wawasan dan pengetahuan yang berguna dalam mempertimbangkan sesuatu sebelum dilakukan pengambilan keputusan dan tindakan. Manfaat lain membaca yaitu seseorang dapat menghasilkan karya tulis baik. Kualitas tulisan seseorang dihasilkan dari sumber baca berkualitas yang telah dibaca sebelumnya. Meskipun

30Penulis lahir di Mojokerto, 05 Maret 1993, penulis merupakan fresh graduate S2 Ilmu Keolahragaan di Universitas Negeri Yogyakarta. Penulis menyelesaikan gelar Sarjana Pendidikan Jasmani dan Keolahragaan di Universitas Negeri Malang (2015), sedangkan gelar Magister Ilmu Keolahragaan diselesaikan di Universitas Negeri Yogyakarta (2020). 
terdapat faktor lain yang mempengaruhi karya tulis seseorang, seperti pengalaman menulis, pemahaman tentang cara menulis yang baik, dan kemampuan merangkum serta menganalisis beberapa karya tulis rujukan menjadi kesatuan karya tulis yang baik.

Pada saat membuka media sosial seperti facebook, twitter, dan instagram seringkali kita dapati tautan menarik yang menghubungkan dengan website lain, seperti berita olahraga, kesehatan, dan politik. Ketika mengklik tautan kemudian membaca beritanya, tanpa disadari membaca telah menjadi gaya hidup sehari-hari. Menjadi kebiasaan umum bahwa setelah membaca berita, seseorang meninggalkan umpan balik berupa komentar. Hal tersebut dibolehkan asalkan tidak memprovokasi, menyinggung, dan tidak mengandung unsur SARA. Kebiasaan membaca rupanya telah lebih dahulu diterapkan warga di negara maju. Mereka membaca di transportasi umum, kantor dan ruang kerja, dan di ruang publik seperti taman, kafe, dan perpustakaan umum. Masyarakat negara maju dikenal menghargai waktu dengan melakukan hal bermanfaat, seperti membaca.

Sebelum kegiatan membaca dilakukan, disarankan kepada pembaca untuk terlebih dahulu menentukan tujuan membaca. Apabila pembaca ingin berimajinasi tentang cerita yang baru dan mengambil hikmah dan pelajaran kehidupan, direkomendasikan untuk membaca karya tulis fiksi. Sedangkan apabila pembaca ingin mendapatkan wawasan, pengetahuan ilmiah, maupun mengetahui unsur kebaruan penelitian maka disarankan pembaca untuk membaca karya tulis non fiksi. Karya tulis secara garis besar dapat dibagi menjadi dua kategori, yaitu fiksi dan non fiksi. Karya tulis fiksi dihasilkan dari imajinasi penulis dan 
khayalan yang membawa pikiran pembaca untuk memikirkan sesuatu sesuai dengan alur cerita. Contoh karya tulis fiksi yaitu novel, cerpen, dongeng, dan legenda. Sedangkan karya tulis non fiksi dihasilkan dari pengalaman emipiris penulis, penelitian, dan pengetahuan yang dapat dijangkau oleh panca indra. Contoh karya tulis non fiksi yaitu buku materi pelajaran, biografi, buku referensi, artikel ilmiah, dan beberapa tugas akhir seperti skripsi, tesis, dan disertasi. Membaca dapat membuka pikiran seseorang agar tidak terdoktrin oleh sesuatu. Dengan membaca, dapat mengubah persepsi sehingga berubah perilakunya dan kebiasaannya menuju ke arah yang lebih baik. Contohnya seorang pemalas baru saja membaca buku motivasi kehidupan akan mendapatkan pencerahan, sehingga berubah persepsi dan kebiasaannya dan terpacu mengoptimalkan waktu untuk berkerja lebih giat.

Selain budaya membaca, penulis juga membahas pentingnya learning by doing sebagai upaya mewujudkan SDM yang unggul di tengah pandemi Covid-19. Secara harfiah learning by doing dapat diartikan belajar langsung bukan hanya melalui teori, namun juga dengan mempraktikkan langsung materi belajarnya. Terdapat adagium pengalaman merupakan guru yang paling baik. Dengan mempraktikkan secara langsung, dapat diperoleh pengalaman belajar yang penting. Selanjutnya dilakukan evaluasi terhadap hasil belajar guna mengetahui sesuatu yang perlu diperbaiki dan ditingkatkan. Pendekatan learning by doing merupakan sesuatu yang umum diterapkan dalam berbagai aspek kehidupan. Pendekatan ini dipilih karena dinilai cukup efektif dan efisien untuk diterapkan dalam kehidupan sehari-hari. 
Tujuan menerapkan pendekatan learning by doing yaitu untuk meningkatkan softskill dan hardskill. Bentuk penerapan learning by doing seperti melakukan pelatihan, diklat, dan pendidikan singkat. Semuanya dilakukan secara intensif sesuai dengan tujuan dan kebutuhan seseorang. Beberapa manfaat penerapan learning by doing yaitu (1) dapat menghemat waktu, (2) dapat diterapkan sesuai dengan kebutuhan pekerjaan saat ini dan di masa depan, (3) penerapan yang mudah sehingga disukai banyak orang, (4) efisiensi biaya, (5) memperoleh perkembangan keterampilan dan hasil yang memuaskan, (6) meningkatkan motivasi dalam bekerja. Konsekuensi belajar dengan pendekatan learning by doing yaitu dibutuhkan seorang instruktur berkompeten di bidangnya dan diharapkan mampu menjadi role model dan evaluator dari tahap belajar yang dilakukan subjek belajar. Saat penerapan learning by doing, subjek belajar mungkin melakukan kesalahan karena mereka belum ahli. Ini hendaknya mendapat perhatian dari instruktur untuk terus mengajarkan, mengevaluasi, dan mengingatkan subjek belajar agar tahapan dilakukan sesuai tujuan kegiatan.

Penemu teori learning by doing ialah John Dewey. Temuannya berawal dari kritik terhadap metode pembelajaran tradisional, dimana pelajar dipaksakan patuh dan tidak mendapat kebebasan dalam mengeksplorasi pembelajaran. Menurutnya metode pendidikan tradisional tidak cukup memadai untuk menyelesaikan permasalahan pembelajaran. John Dewey merupakan seorang filsuf berkebangsaan Amerika Serikat yang menghasilkan konsep dan ide besar berpengaruh terhadap perkembangan dunia. Dia mendirikan sekolah untuk mempraktikkan dan menguji teorinya. Karyanya yang paling terkenal yaitu buku berjudul 
"Experience and Education". Buku ini mengulas tentang pendidikan berbasis pengalaman. Menurut John Dewey, sesungguhnya pendidikan berlandaskan pada pengalaman yang mendidik. Pada prinsipnya, learning by doing menegaskan adanya kesinambungan pengalaman dan interaksi. Kesinambungan berarti pengalaman yang terjadi berperan dan berkaitan dengan pengalaman selanjutnya. Interaksi berarti pengalaman lampau dapat menstimulasi seseorang bertindak, dan dihubungkan dengan pengalaman selanjutnya.

Saat ini banyak lapangan pekerjaan mensyaratkan Sumber Daya Manusia berkualitas dalam proses rekrutmen kerja. Banyak calon pegawai yang ditolak perusahaan karena belum memenuhi kualifikasi yang dibutuhkan. Pada era globalisasi dan modernisasi sekarang, tingkat persaingan SDM semakin ketat. Individu diharapkan mampu melakukan pengembangan diri agar dapat menjawab tantangan zaman. Pengembangan SDM merupakan upaya membentuk SDM unggul dengan keterampilan kerja dan kepribadian yang baik dalam menjaga hubungan dengan atasan dan rekan kerja, juga memiliki loyalitas terhadap organisasi perusahaan dan institusi tempat dia bekerja. Pengembangan SDM diterapkan dengan mengadakan pelatihan, pendidikan, pembinaan, rekrutmen pegawai, dan perbaikan sistem.

Konsep SDM unggul menurut Narwan Kelana (2019) berarti manusia dapat menggerakkan manusia yang lain. Seseorang harus cerdas dan terampil terlebih dahulu, untuk dapat menggerakkan organisasi di perusahaan maupun institusi tertentu. Karakter dan kepribadian juga merupakan indikator lain untuk mewujudkan SDM yang unggul. Hal tersebut didasarkan pada asumsi secerdas dan 
seterampilnya seseorang apabila tidak memiliki karakter dan kepribadian yang baik maka dia akan kesulitan dalam mendorong dan menggerakkan manusia lain. Konsep SDM unggul dijelaskan Rafif Zain (2021) dapat dimulai dari akarnya yaitu dengan memastikan kesehatan ibu hamil. Sejak dalam kandungan, kesehatan bayi harus diupayakan dengan baik. Hal ini juga dilanjutkan dalam tumbuh kembang anak yaitu pada usia balita dan usia sekolah, kesehatan merupakan prioritas untuk mewujudkan SDM yang unggul. Kombinasi antara nutrisi yang tercukupi dengan lingkungan sosial yang baik turut mempengaruhi tumbuh kembang anak. Pendidikan guna mencerdaskan anak bangsa harus terjamin keberlangsungannya sampai dengan minimal tingkat menengah atas, sehingga dapat menghasilkan manusia dengan keterampilan hidup. SDM unggul berarti memiliki kemampuan lebih dibandingkan dengan kemampuan SDM rata-rata. SDM unggul berarti SDM yang dapat mengembangkan dan menyeimbangkan IPTEK (ilmu pengetahuan dan teknologi) dan IMTAQ (iman dan taqwa).

Dewasa ini pandemi Covid-19 belum berakhir. Hal inilah yang menjadi dasar Pemerintah Indonesia melanjutkan pemberlakuan pembatasan kegiatan masyarakat. Hal tersebut bedampak pada fasilitas publik yang ditutup, seperti perpustakaan umum, gedung kampus, dan prasarana olahraga seperti kolam renang, taman olahraga, dan lapangan basket. Semua kegiatan dan pekerjaan dihimbau agar dilakukan dari rumah. Hal ini dilakukan dalam rangka membatasi mobilitas manusia demi memutus rantai penularan virus corona. Taat terhadap protokol kesehatan seperti memakai masker, mencuci tangan dengan sabun, dan menjaga jarak tetap dilakukan 
sebagai usaha melindungi diri dari penularan virus corona. Program vaksinasi juga sudah diberikan kepada masyarakat.

Pada masa pandemi Covid-19, SDM unggul dibutuhkan sebagai agen perubahan di masyarakat. Sebagai contoh yaitu dengan kecerdasan dan keterampilan yang dimiliki, seorang lulusan perguruan tinggi dapat menggerakkan perekonomian masyarakat sekitar dengan cara merekrut warga sekitar untuk meningkatkan produksi tahu-tempe. Saat pandemi, banyak keluarga yang memasak tahu-tempe dari rumah. Hal ini karena tahu-tempe lezat disajikan hangat dan dapat divariasi olahan masakannya, seperti tempe penyet, tahu bakso, dijadikan sayur, dan sebagainya. Hal ini membuat permintaan terhadap tahu-tempe meningkat. Kondisi inilah yang berhasil dimanfaatkan seorang lulusan perguruan tinggi tersebut untuk memberdayakan ekonomi masyarakat di masa pandemi dengan cara meningkatkan produksi tahu-tempe dan melibatkan warga.

Dalam rangka mewujudkan SDM unggul pada masa pandemi Covid-19, diperlukan usaha terus menerus dalam peningkatan kecerdasan dan keterampilan. Kecerdasan seseorang dapat ditingkatkan melalui budaya membaca, sedangkan keterampilan seseorang dapat ditingkatkan dengan pendekatan learning by doing. Saat pandemi, membaca dapat dilakukan di rumah, seperti membaca di kamar, ruang tamu, dan halaman depan rumah. Perlu dilakukan pengaturan ruangan agar diperoleh kenyamanan dalam membaca, seperti pengaturan cahaya lampu, sirkulasi udara, kebersihan, dan aroma ruangan. Bahan bacaan yaitu karya tulis fiksi dan non fiksi. Penerapan learning by doing pada masa pandemi yaitu dengan cara mengikuti kegiatan 
pelatihan, pembelajaran, dan diklat secara online. Untuk itulah diperlukan akses jaringan internet yang memadai agar kegiatan learning by doing secara online dapat berjalan dengan lancar. Disarankan kepada subjek belajar agar bergabung dengan komunitas, karena pendekatan learning by doing biasanya diselenggarakan dengan melibatkan banyak peserta. Melalui komunitas, seseorang dapat saling berbagi dan bertukar pikiran dengan teman belajar lain maupun dengan instruktur. Semoga kita dapat menjadi SDM unggul pada masa pandemi Covid-19 dengan menerapkan budaya membaca dan learning by doing. 